Original Article

\title{
AMELIORATIVE ROLE OF BEE HONEY AND ROYAL JELLY AGAINST CISPLATIN INDUCED ALTERATION IN HEMATOLOGICAL PARAMETERS IN MALE WISTER ALBINO RAT
}

\author{
WAYKAR BHALCHANDRA*, YAHYA ALI ALQADHI** ${ }^{*}$ A. S. NINAWE ${ }^{* * *}$
}

${ }^{*, * *}$ Department of Zoology, Dr. Babasaheb Ambedkar Marathwada University, Aurangabad-(M. S), ${ }^{* * *}$ Department of Biotechnology, Government of India, CGO Complex, Lodhi Road, New Delhi-110003

Email: bbwaykar@gmail.com

Received: 15 Oct 2017 Revised and Accepted: 08 Mar 2018

\section{ABSTRACT}

Objective: This study aims to investigate the ameliorative role of dietary bee honey and royal jelly against cisplatin-induced alterations in hematological parameters in male wistar albino rat.

Methods: Male wistar albino rats of same age and weight were randomly divided into four groups; G, I: control group which was given $0.9 \%$ saline, G: II: cisplatin (7 mg/kg/d) was injected intraperitoneally for $15 \mathrm{~d}, \mathrm{G}$, III bee honey with royal jelly (500 mg/kg/d of honey and $100 \mathrm{mg} / \mathrm{kg} / \mathrm{d}$ of royal jelly) fed orally daily for $15 \mathrm{~d}, \mathrm{G}$, IV: cisplatin $(7 \mathrm{mg} / \mathrm{kg} / \mathrm{d})$ was injected intraperitoneally and honey (500 mg/kg/d) and royal Jelly (100 $\mathrm{mg} / \mathrm{kg} / \mathrm{d}$ ) fed orally daily for $15 \mathrm{~d}$. The hematological parameters like total number of white blood cells (WBCs), red blood cells (RBCs), platelets, \% of hemoglobin ( $\mathrm{Hb}$ ), and mean values of packed cell volume (PCV), mean corpuscular volume (MCV) and mean corpuscular hemoglobin concentration (MCHC) were measured by using automated hematology system.

Results: Cisplatin treated rats revealed a significant decrease in total number of white blood cells (WBCs), red blood cells (R. B. Cs), platelets, percentage of hemoglobin (Hb), and mean values of packed cell volume (PCV), corpuscular volume (MCV) and corpuscular hemoglobin concentration (MCHC) as compared to control group. Royal jelly and honey treated group of rats revealed a significant increase in all blood parameters compared to control group. Dietary bee honey with royal jelly along with cisplatin-treated rats revealed significant increas as compared to animals treated with cisplatin (G, II) and the computed significant valus for the above parameters are 10.00, 2.30, 8,54, 12.00, 35.00, 47.40 and 32,30 respectively.

Conclusion: Bee honey and royal jelly could be used as dietary preventive natural products against cisplatin-induced hematological alterations during the treatment of cancer.

Keywords: Wister albino Rats, Hematology, Cisplatin, Honey, Royal jelly, Ameliorative

(C) 2018 The Authors. Published by Innovare Academic Sciences Pvt Ltd. This is an open access article under the CC BY license (http://creativecommons.org/licenses/by/4.0/) DOI: http://dx.doi.org/10.22159/ijpps.2018v10i4.23153

\section{INTRODUCTION}

Cisplatin is one of the most cytotoxic agents and is widely used to treat a variety of cancers, but it is associated with toxic side effects. The oxidative stress through the formation of free radicals is one of the mechanisms of cisplatin-induced toxicity [1]. The free radical scavengers, or which prevent the formation of the reactive hydroxyl free radicals, can provide protection against cisplatin-induced hematotoxicity, especially blood parameters [2]. Different natural products and dietary compounds have been recently investigated and evaluated as potential protective antioxidant agents against cisplatin-induced toxicity [3]. Honey and royal jelly are natural dietary substances, which previously tested to ameliorate the toxic side effects of a different substance, through their antioxidant, radical scavenging and antiperoxidative activity $[4,5]$.

Blood delivers requisite materials such as nutrients and oxygen and carri away the waste products from the cells. It contains RBCs, WBCs and platelets, which are suspended in a fluid medium; plasma [6, 7]. The measurement of hematological parameters erythrocytes, leukocytes, platelets and concentration of hemoglobin are some of the most frequently performed clinical laboratory tests in which variations in the count of blood cells signal regarding diseases or ill health of human body. For overall health assessment and diagnosis of many disorders, complete blood count is required.

Consequently, the aim of the present study was to investigate the ameliorative role of dietary bee honey and royal jelly against cisplatin-induced alterations in hematological parameters in male wistar albino rat.

\section{MATERIALS AND METHODS}

Animals

Healthy male wistar albino rats weighing 200-250 gm (10-12 w age) were obtained from the animal house of R. C. Patel Institute of
Pharmaceutical Education and Research, Shirpur-India. All the experimental procedures were carried out in accordance with the guidelines of the committee for the purpose of control and supervision of experiments on the animal (CPCSEA). All animal experiments were approved by the Institutional Animal Ethics Committee (IAEC) of RCPIPER, Shirpur (Reg No.-651/P0/ReBi/ S/02/CPCSEA).

\section{Housing conditions}

The rats were housed in standard plastic cages. The bedding material of the cages was changed every day. Maximum of 3 rats housed per polypropylene cage having a size of $32 \times 11 \mathrm{~cm}$ with stainless steel grill top mesh having facility for holding food palate and a water bottle. The rats were allowed free access to food, diet and water throughout the experimental period. All animals were housed in an air-conditioned room at a temperature range between $22-25{ }^{\circ} \mathrm{C}$, relative humidity in between $30 \%-60 \%$ and with a 12 hour light-dark cycle.

\section{Acclimatization}

Selected rats were randomly divided into four groups containing 6 rats in each group and were allowed to acclimatize to laboratory conditions for $7 \mathrm{~d}$ prior to experimentation.

\section{Water}

Water processed by reverse osmosis and Ultraviolet (UV) light was supplied ad libitum to the rats.

\section{Chemicals}

Cisplatin was purchased from (Cipla Ltd company-Goa-India). Bee honey and royal jelly collected directly from the Apis mellifera colonies located in the university campus. Food pallet was 
purchased from Nutrivet Life sciences, Pune, Maharashtra, India. All other chemicals used in the experiment were of analytical grade.

\section{Preparation of royal jelly and honey}

$500 \mathrm{mg} / \mathrm{kg} / \mathrm{d}$ of honey and $100 \mathrm{mg} / \mathrm{kg} / \mathrm{d}$ of royal jelly were dissolved in distilled water and administered through an intragastric tube through the mouth. The doses were weighed on digital scales, where the dose relies on animal weight, in which every single gram of the experimental rat should receive $0.5 \mathrm{mg}$ of honey and $0.1 \mathrm{mg}$ of royal jelly.

\section{Experimental design}

For the study, 24 adult male wister albino rats of $10-12 \mathrm{w}$ age and with $200-250 \mathrm{~g}$ weight randomly divided into 4 groups; each group consisting of 6 rats and were treated for $15 \mathrm{~d}$ as below:

Group I (Control): $0.9 \%(10 \mathrm{ml} / \mathrm{kg} / \mathrm{d})$ saline solution was administrated for $15 \mathrm{~d}$.

Group II (Cisplatin): Cisplatin $(7 \mathrm{mg} / \mathrm{kg} / \mathrm{d})$ intraperitoneal injection for $15 \mathrm{~d}[8,9]$.

Group III (bee honey+royal jelly): Bee honey $(500$ $\mathrm{mg} / \mathrm{kg} / \mathrm{d})+$ Royal jelly $(100 \mathrm{mg} / \mathrm{kg} / \mathrm{d})$ orally administrated for $15 \mathrm{~d}$ $[8,10]$.

Group IV (Cisplatin+bee honey+royal jelly): $7 \mathrm{mg} / \mathrm{kg} / \mathrm{d}$ of cisplatin intraperitoneal injection along with $500 \mathrm{mg} / \mathrm{kg} / \mathrm{d}$ of honey+100 mg/kg/d of royal jelly orally were through an intragastric tube for $15 \mathrm{~d}$.

Blood collection: After $15 \mathrm{~d}$ of treatment, blood samples were collected via retro-orbital puncture under light ether anesthesia. Blood collected was put in tubes, containing a substance of Ethylenediaminetetraacetic acid (EDTA) (15-20 IU per ml of blood), to check the number of WBC, RBC, PLT, PCV, Hb, MCV, MCH and MCHC [11].

\section{Hematological assay}

The hematological parameters like a total number of WBCs, RBCs, platelets, \% hemoglobin ( $\mathrm{Hb})$, and mean values $\mathrm{MCV}, \mathrm{MCH}$ and MCHC were measured by using automated Hematology System, Sysmex Exigo, Box 42056, SE-126 13 Stockholm, Sweden.

\section{Statistical analysis}

All data were expressed as mean \pm S. E. M and statistically analyzed using Graph Pad Prism 7 for Windows (Prism Inc, Chicago, IL, U. S. A). The statistical significance of differences among different study groups was evaluated by one-way analysis of variance (ANOVA) followed by Bonferroni's multiple comparison tests as a post hoc test. P value of 0.05 or less was taken as a criterion for a statistically significant difference.

\section{RESULTS}

Effect of treatment of cisplatin (G, II), bee honey and royal jelly (G, III), and the combined treatment of cisplatin with bee honey and royal jelly (G, IV) on hematological parameters of male wistar albino rats were evaluated in comparison with control group (G, I) for the period of $15 \mathrm{~d}$ and obtained results were summarized in (table 1).

The results demonstrated that cisplatin treated rats, (G, II), exhibited significant decrease in the total number of white blood cells (WBC), red blood cells (RBC), platelets (PLT), hemoglobin\% $(\mathrm{Hb})$ and mean values of packed cell volume (PCV), mean corpuscular volume $(\mathrm{MCV})$, mean corpuscular hemoglobin $(\mathrm{MCH})$ contents and the percentages decreased was $22.7 \%, 55.5 \%, 36.25 \%, 14.9 \%, 34.1 \%$, $19.3 \%$ and $24.9 \%$, respectively as compared to the control group rats.

In the present study, it was observed that after honey and royal jelly treatment (G, III), total number of white blood cells (WBC), red blood cells (RBC), platelets (PLT), hemoglobin (Hb)\% and mean values of packed cell volume (PCV), mean corpuscular volume (MCV) and mean corpuscular hemoglobin $(\mathrm{MCH})$ of experimental rats showed a significant increase as compared to the control group and the percentages of increase was $8.3 \%, 8.9 \%, 11.82 \%, 11.8 \%, 2.43 \%$, $2.68 \%$ and $0.57 \%$, respectively.

After combining treatment of cisplatin along with honey and royal jelly (G, IV), the total number of white blood cells (WBC), red blood cells (RBC), platelets (PLT), haemoglobin (Hb) \% and mean values of packed cell volume (PCV), mean corpuscular volume (MCV) and mean corpuscular hemoglobin $(\mathrm{MCH})$ of experimental rats was significantly increased as compared to animals treated with cisplatin (G, II). The percentage was $17.64 \%, 36.4 \%, 42.5 \%, 11.1 \%, 29.6 \%$, 12.5.1\%, 23.2\%, respectively.

Table 1: Haematological parameters of control and treated groups

\begin{tabular}{|c|c|c|c|c|}
\hline \multirow[t]{2}{*}{ Parameter } & \multicolumn{4}{|l|}{ Groups } \\
\hline & Control (G,I) & Cisplatin (G,II) & Honey and royal jelly (G,III) & Cisplatin with Honey and royal jelly (G, IV) \\
\hline Total WBC & $11.00 \pm 0.088$ & $8.50 \pm 0.17^{* * *} \mathrm{a}$ & $12.00 \pm 0.30 \mathrm{a}$ & $10.00 \pm 0.19^{* *} \mathrm{~b}$ \\
\hline$\times 10^{3} / \mathrm{Cmm}$ & & $\#-22.7 \%$ & $\#+8.3 \%$ & $\mathrm{w}+17.64 \%$ \\
\hline Total RBC & $3.80 \pm 0.421$ & $1.69 \pm 0.244 * a$ & $4.14 \pm 0.439 \mathrm{a}$ & $2.30 \pm 0.655^{* *} \mathrm{~b}$ \\
\hline$\times 10^{6} / \mathrm{Cmm}$ & & $\#-55.5 \%$ & \#+8.9\% & $w+36.09 \%$ \\
\hline Platelets $\times$ & $9.39 \pm 0.202$ & $5.99 \pm 0.489 * * * a$ & $10.50 \pm 0.420 \mathrm{a}$ & $8.54 \pm 0.362^{* * *} \mathrm{~b}$ \\
\hline$\left(10^{5} / \mathrm{cmm}\right)$ & & $\#-36.25 \%$ & \#+11.82\% & $w+42.57 \%$ \\
\hline $\begin{array}{l}\text { Haemoglobin } \\
(\%)\end{array}$ & $12.70 \pm 0.251$ & $\begin{array}{l}10.80 \pm 0.5779^{* *} \mathrm{a} \\
\#-14.9 \%\end{array}$ & $\begin{array}{l}14.20 \pm 0.209 a \\
\#+11.8 \%\end{array}$ & $\begin{array}{l}12.00 \pm 0.229 * b \\
w+11.1 \%\end{array}$ \\
\hline PCV (\%) & $41.00 \pm 0.43$ & $\begin{array}{l}27.00 \pm 2.4^{* * *} \mathrm{a} \\
\#-34.1 \%\end{array}$ & $\begin{array}{l}42.00 \pm 0.32 \mathrm{a} \\
\#+2.43 \%\end{array}$ & $\begin{array}{l}35.00 \pm 1.4 * b \\
W+29.6 \%\end{array}$ \\
\hline MCV (\%) & $52.20 \pm 0.850$ & $\begin{array}{l}42.10 \pm 0.186^{* * *} \mathrm{a} \\
\#-19.3 \%\end{array}$ & $\begin{array}{l}53.60 \pm 0.837 a \\
\#+2.68 \%\end{array}$ & $\begin{array}{l}47.40 \pm 1.14^{* *} b \\
W+12.5 \%\end{array}$ \\
\hline $\begin{array}{l}\mathrm{MCHC} \\
(\mathrm{gm} / \mathrm{dl})\end{array}$ & $34.90 \pm 0.196$ & $\begin{array}{l}26.20 \pm 1.20^{* * *} \mathrm{a} \\
\#-24.9 \%\end{array}$ & $\begin{array}{l}35.10 \pm 0.479 a \\
\#+0.57 \%\end{array}$ & $\begin{array}{l}32.30 \pm 0.933^{* * *} \mathrm{~b} \\
\mathrm{~W}+23.2 \%\end{array}$ \\
\hline
\end{tabular}

1. \pm indicate SD of three observations, 2. \# (+) or (-) indicates percent variation over control, 3. w (+) or (-) indicates percent variation over cisplatin, 4. Values are significant at ${ }^{*} P<0.001,{ }^{* *} P<0.01,{ }^{* * *} P<0.05$, 5. NS (Not significant), 6 . a $=P<0.001,{ }^{* *} P<0.01,{ }^{* * *} P<0.05$ values compared with normal control, 7. $\mathrm{b}=P<0.001,{ }^{* *} P<0.01,{ }^{* * *} P<0.05$ values compared with cisplatin group, 8 . WBC $=$ White blood cell, $9 . \mathrm{RBC}=\mathrm{Red}$ blood cells, $10 . \mathrm{PCV}=$ Packed cell volume, 11. MCV = Mean corpuscular volume, 12 . MCHC = Mean hemoglobin concentration.

\section{DISCUSSION}

In the present study it was observed that due to cisplatin treatment rats for $15 \mathrm{~d}$, the total number of white blood cells (WBC), red blood cells (RBC), platelets (PLT), hemoglobin $\mathrm{Hb} \%$, and mean values of packed cell volume (PCV), mean corpuscular volume (MCV) and mean corpuscular hemoglobin (MCH) were significantly decreased. Similar results were reported by many authors [12-9].

The results demonstrate that after $15 \mathrm{~d}$ of cisplatin treated rats, the total number of white blood cells (WBC) was significantly decreased. This might be due to infection and inflammation during cisplatin 
treatment. The main molecular mechanism of cisplatin is myelotoxicity is due to its ability to bind with cellular DNA and render the cell incapable of replication [20]. Beside this, another mechanism of cisplatin is its ability to induce oxidative stress [21]. Reactive oxygen species are toxic to bone marrow cells and probably can trigger apoptosis and affect cell cycle, causing anemia and a decrease in leukocyte count [22]. Myelosuppression resulting in leukopenia and thrombocytopenia is a frequent and a major complication of cancer chemotherapy [23]. Many authors [24-8, 145] observed that the number of WBC was decreased after exposure to cisplatin administration.

After $15 \mathrm{~d}$ of cisplatin treatment to rats, the platelet count was significantly decreased compared to control group. This might be due to cisplatin inhibiting bone marrow activity or could be due to decreased production or increased consumption of platelets or due to the increased platelets aggregation [29]. Cisplatin causes oxidative stress in human platelets and lymphocytes, which might reflect on their life expectancy, the induction of apoptosis, and thereby ultimately reduced the number of these cells in the blood of experimental animals. However, the decrease in the WBCs number could be the consequence of infection and inflammation during cisplatin treatment and cisplatin metabolism in the experimental rats. [30]. Cisplatin reduced the platelet count in rats under experiment [25] and depleted the platelet number and caused cumulative anemia in rats [13].

After $15 \mathrm{~d}$ of cisplatin treatment rats, the total number of RBC and $\mathrm{Hb} \%$ were significantly decreased as compared to control. Similar results were reported by many authors $[12-4,16,18,25,28]$. The previous results suggested that there was an etiological relationship between anemia and cisplatin treatment. This relation could be explained through different mechanisms, including the destruction of bone marrow cells or increased osmotic fragility of RBC. Thus, cisplatin therapy might lead to anemia as a result of either suppression of the activity of hematopoietic tissues, impaired erythropoesis, and accelerated RBCs destruction because of the altered RBCs membrane permeability, increased RBCs mechanical fragility, and/or defective iron metabolism [13].

The reduction of $\mathrm{RBC}$ and $\mathrm{Hb} \%$ attributed to the hemorrhage or hemolysis or because of impaired blood formation in bone marrow due to cisplatin toxicity and that led to imbalance between production and loss, inhibition of DNA synthesis in bone marrow precursor cells, leaving both RNA and protein synthesis intact and inhibition of many steps of heme biosynthesis in rats, as result of cisplatin use [31]. The reduction in the $\mathrm{Hb} \%$ is related to suppression of erythropoiesis and iron supply to erythroblasts $[32,33]$.

It also seems less likely that the reduced RBC count was a result of hematopoietic colony forming unit (CFU-E) maturation disturbances. Haemolyticanaemia has been reported in patients treated repeatedly with Cisplatin [34-6]. Antibodies reacting with Cisplatin-RBC-membrane complexes [34] can also cause hemolysis.

It was also found that cisplatin therapy inhibited the production of renal erythropoietin, which resulted in a lower RBC production. The nephrotoxic effect of cisplatin showed a negative effect on erythropoiesis that resulted in the low production and the count of RBCs [12]. Cisplatin is said to cause anemia by interfering in the iron metabolism [37].

Due to cisplatin treatment rats for $15 \mathrm{~d}$, mean values of packed cell volume (PCV), mean corpuscular volume (MCV) and mean corpuscular hemoglobin $(\mathrm{MCH})$ values were significantly decreased as compared to control group. Similar results were reported by a number of authors $[26,16,18]$.

Following the treatment with cisplatin, decreased MCV, MCH and reduced MCHC, suggest that a microcytic hypochromic anemia was due to the suppression of erythropoiesis [37]. It is reported that reactive oxygen species (ROS) increases hemoglobin glycation and erythrocyte fragility and bone marrow can be damaged by direct oxidation [38, 39]. More specifically haemoglobin-derived iron might contribute to the pathogenesis of cisplatin by inducing the oxidative stress $[31,40]$.

Thus, in the present study, it was observed that the decrease in the $\mathrm{MCV}, \mathrm{MCH}$ and MCHC after exposure to cisplatin was attributed to the production of erythrocytes with lower MCV, MCH and MCHC and these parameters closely related to $\mathrm{Ht}$ levels and $\mathrm{Hb}$. $\mathrm{Hb}$ data could be strongly influenced by MCV, MCH and MCHC values [41].

[42-3], it was found that cisplatin was more toxic to earlier haemopoietic progenitor cells than the mature ones. It was suggested that anemia could be due to the difference in time of maturation of the erythroid series. However, in a recent study [34] hemolysis was blamed for the production of anemia [44].

The above-mentioned effects of cisplatin could be due to their ability to form free radicals [45]. This fact may ensure the hypothesis of the ability of cisplatin to form free radicals, which have been implicated as playing a role in the etiology of many alterations [46].

The success of a chemotherapy is dependent not only on effectively removing tumor cells but also on reducing the related immunosuppressive complications that are primarily caused by apoptosis of circulating leukocytes cells (leucopenia). Rat's response to cisplatin chemotherapy caused severe immunosuppressive conditions, as reflected in a lower WBC count.

In the present study it was observed that after honey and royal jelly treatment (G, III), the total number of white blood cells (WBC), red blood cells (RBC), hemoglobin \% (Hb), platelets (PLT), and the mean values of packed cell volume (PCV), mean corpuscular volume (MCV) and mean corpuscular hemoglobin (MCH) of experimental rats were significantly increased as compared to control group.

Antioxidants can prevent cell damage caused by the action of reactive oxygen species (ROS) and free radicals [47]. The antioxidant activities are related to a number of different mechanisms, such as free radicalscavenging, hydrogen-donation, singlet oxygen quenching, metal ion chelation, and acting as a substrate for radicals such as superoxide and hydroxyl [48]. Recently, royal jelly has received particular attention as a highly efficient antioxidant and has the free radical scavenging capacity [49]. It contains many important compounds with biological activity such as free amino acids, proteins, sugars, fatty acids, minerals, and vitamins [50]. Honey is a natural antioxidant, which may contain flavonoids, ascorbic acid, tocopherols, catalase, and phenolic compounds all of which work together to provide a synergistic antioxidant effect, scavenging and eliminating free radicals [51-54].

In the present study it was observed that after combined treatment of cisplatin along with honey and royal jelly (G, IV), the total number of white blood cells (WBC), red blood cells (RBC), blood platelets (PLT), hemoglobin $\%(\mathrm{Hb})$ and mean values of packed cell volume (PCV), mean corpuscular volume (MCV) and mean corpuscular hemoglobin (MCH) of experimental rats were significantly increased as compared to animal treated with cisplatin (G, II). Honey and royal jelly have a protective role against many drugs, wherever [55] the honey protective effects on organs through the improvement in the hematological parameters (RBCs, WBCs and Platelets) because of decreased lipopolysaccharide in rats. Honey is reported to attenuate the hematological, effects induced by gentamicin $[56,45]$. Natural honey significantly $(\mathrm{P}<0.05)$ restored $\mathrm{Hb}$ content, RBC, PCV, platelet and WBC close to control values in wistar albino rats fed hydrocarbon contaminated diets [57].

The royal jelly has a hemato-curative role against azathioprine [17]. Honey has a hemato-curative role against zinc [58] and also it is reported that honey effects on amikacin-induced toxicity on hematological parameters [10].

The present study showed the improvement in the tested blood parameters as erythrocytes, hemoglobin, leukocytes, platelets and the mean value of packed cell volume (PCV), mean corpuscular volume (MCV) and mean corpuscular hemoglobin $(\mathrm{MCH})$ indicates that honey and royal jelly administration prevented blood cell damage by maintaining the integrity of cells. Administration of royal jelly to rats ameliorated the effect of radiation that induced oxidative stress and hematological alterations [56].

\section{CONCLUSION}

Cisplatin caused a decrease in the total number of red blood cells (RBC), blood platelets (PLT), hemoglobin (HB) \% and mean values of packed cell volume (PCV), mean corpuscular volume (MCV) and mean corpuscular hemoglobin (MCH), whereas honey and royal jelly 
reversed these decreases. A high significant protective and curative effect on the studies on blood parameters due to honey and royal jelly indicates that honey and royal jelly should be supplemented to the patient when cisplatin chemotherapy is executed.

\section{AUTHORS CONTRIBUTIONS}

All persons who meet authorship criteria are listed as authors, and all authors certify that they have participated sufficiently in the work to take public responsibility for the content, including participation in the concept, design, analysis, writing, or revision of the manuscript.

\section{CONFLICT OF INTERESTS}

Declared none

\section{REFERENCES}

1. Kart A, Yilmaz C, Musa K, Hasan O. Caffeic acid phenethylester (CAPE) ameliorates cisplatin-induced hepatotoxicity in rabbits. Exp Toxicol Pathol 2010;62:45-52.

2. Pradeep K, Mohan C, Gobianand K, Karthikeyan S. Silymarin modulates the oxidant-antioxidant imbalance during diethyl nitrosamine-induced oxidative stress in rats.Eur J Pharmacol 2007;560:110-6.

3. Ohno S, Strebell FR, Stephens LC, Siddik ZH, Baba H, Makino M, et al. Hematological toxicity of carboplatin and cisplatin combined with whole body hyperthermia in rats. Br J Cancer 1993;68:469-74.

4. Shirzad M, Kordyazdi R, Shahinfard N, Nikokar M. Does royal jelly affect tumor cells. J Herbmed Pharmacol 2013;2:45-8.

5. Atrooz OM, Al-Sabayleh MA, Al-Abbadi SY. Studies on physical and chemical analysis of various honey samples and their antioxidant activities. J Bio Sci 2008;8:1338-42.

6. Alemu Y, Atomsa A, Sahlemariam Z. Hematology. Lecture notes for medical laboratory students. Jimma University, Ethiopia: Ethiopia Public Health Training Initiative; 2006.

7. Manzone TA, Dam HQ, Soltis D, Sagar VV. Blood volume analysis: A new technique and new clinical interest reinvigorate a classic study. J Nucl Med Technol 2007;35:55-63.

8. Yildirim S, Kisa F, Karadeniz A, Yildirim A, Karakoc A, Can I, et al. Effects of pomegranate seed extract on liver paraoxonase and bcl-xL activities in rats treated with cisplatin. J Med Plant Res 2012;6:2317-23.

9. Ashry K, Elkady AA. Royal jelly modulates the hepatotoxic effect of rats treated with cisplatin. ESNSA 2014;47:172-80.

10. Abd Ali AR, Ismail SH. The protective effect of honey against amikacin-induced nephrotoxicity in rats. Iraqi J Pharm Sci 2012;21:85-93.

11. Dacie JU, Lewis SM. Practical haematology. Edinburgh: Churchill Livingston. $5^{\text {th }}$ ed. Longman Publishers; 1975.

12. Hassan S, Chibber I, Naseem. Ameliorative effect of riboflavin on the cisplatin-induced nephrotoxicity and hepatotoxicity under photo-illumination. Food Chem Toxicol 2010;48:2052-8.

13. Markovic SD, Zizic JB, Djacic DS, Obradovic AD, Curcic MG, Cvetkovic DM, et al. Alteration of oxidative stress parameters in red blood cells of rats after chronic in vivo treatment with cisplatin and selenium arch. Biol Sci Belgrade 2011;63:991-9.

14. Nematbakhsh M, Ashrafi F, Safari T, Talebi Nasri H, Mortazavi M, Khazaei M, et al. Molecular chaperones and proteostasis regulation during redox imbalance. Redox Biol 2014;2:323-32.

15. Oruc E, Kara A, Can I, Karadeniz A, Simsek N. Caspase-3 and CD68 Immunoreactivity in lymphoid tissues and haematology of rats exposed to cisplatin and L-carnitine. Kafkas Universitesi Veteriner Fakultesi Dergisi 2012;18:871-8.

16. Nasr AY. Protective effect of aged garlic extract against the oxidative stress induced by cisplatin on blood cells parameters and hepatic antioxidant enzymes in rats. Toxicol Reports 2014;6:682-91.

17. Ahmeda WM, Khalaf AA, Moselhyc WA, Safwat GM. Royal jelly attenuates azathioprine-induced toxicity in rats. Environ Toxicol Pharmacol 2014;37:431-7.

18. Maheswari R, Manohari S. Syzygium cumini (L.) seeds extract ameliorates cisplatin-induced hepatotoxicity in male Wistar rats. Int J Pharm Sci Res 2015;6:444-50.
19. Zammble DB, Lippared SJ. Cisplatin and DNA repair in cancer chemotherapy. Trends Biochem Sci 1995;20:435-9.

20. Nowrousian MR, Schmidt CG. Effects of cisplatin on different haemopoietic progenitor cells in mice. $\mathrm{Br} \mathrm{J}$ Cancer 1982;46:397-402.

21. Malarczyk E, Kandefer-Szerszen M, Jarosz-Wilkołazka A. The influence of very low doses of cisplatin on tumor cell proliferation in vitro and on some hematological and enzymatic parameters of healthy rats. Nonlinearity Biol Toxicol Med 2003;1:123-37.

22. Hoagland HC. Hematologic complications of cancer chemotherapy. Seminoncol 1982;9:95-102.

23. Mahadev MN. Protective effects of cystone, a polyherbal ayurvedic preparation, on cisplatin-induced renal toxicity in rats. J Ethnopharmacol 1998;62:1-6.

24. Bhavaraju VM, Reed NS, Habeshaw T. Acute toxicity of concomitant treatment of chemoradiation with single-agent cisplatin in patients with carcinoma of the cervix. J Physiol Sci 2004;17:90-7.

25. Khynriam D, Prasad SB. Hematotoxicity and blood glutathione levels after cisplatin treatment of tumour-bearing mice. Cell Biol Toxicol 2001;17:357-70.

26. Geyikog F, Suat C, Olak HT, Murat B, Koc K, Hosseinigouzdagani $\mathrm{M}$, et al. Oleuropein ameliorates cisplatin-induced hematological damages via restraining oxidative stress and DNA injury. Indian J Hematol Blood Transfusion 2016;33:348-54.

27. Longchar A, Prasad SB. Ascorbic acid (vitamin c) ameliorates cisplatin-induced hematotoxicity in tumour-bearing mice. World J Pharm Pharm Sci 2016;5:1870-91.

28. Sirage HM. Biochemical and hematological studies for the protective effect of Oyster Mushroom (Pleurotusostreatus) against glycerolinduced acute renal failure in rats. J Biol Sci 2009;9:746-52.

29. Olas B, Wachowicz B, Majsterek I, Blasiak J. Resveratrol may reduce oxidative stress induced by platinum compounds in human plasma, blood platelets and lymphocytes. Anticancer Drugs 2005;16:659-65.

30. Zazgornik J. Azathioprine-induced macrocytosis and red cell aplasia in renal transplant patients. Nephrol Dial Transplant 1997;12:2689-91.

31. Baliga $\mathrm{R}$, Zhang Z, Baliga M, Ueda N, Shah SV. In vitro and in vivo evidence suggesting a role for iron in cisplatin-induced nephrotoxicity. Kidney Int 1998;53:394-401.

32. Cazzola M. Mechanisms of anaemia in patients with malignancy: implications for the clinical use of recombinant human erythropoietin. Med Oncol 2000;17:11-6.

33. Getaz EP, Beckly S, Fitzpatrick J, Dozier A. Cisplatin-induced haemolysis. N Engl J Med 1980;302:334-5.

34. Levi A, Aroney RS, Dalley DN. Hemolytic anemia after cisplatin treatment. Br Med J 1981;282:2003-4.

35. Van Nguyen B, Jaffe N. Cisplatin induced anaemia. N Engl J Med 1981;303:110-1.

36. Maloisel F, Kurtz JE, Andres E, Gorodetsky C, Dufour P, Oberling F. Platin salts-induced hemolytic anemia: cisplatin-and the first case of carboplatin-induced hemolysis. Anticancer Drugs 1995;6:324-6.

37. Gao LP, Li Z, Guo ZY, Zhao YM. The effects of vitamin C on DDPinduced anemia in rats. Toxicol Mech Methods 2013;23:383-8.

38. Ghosh S, Bandyopadhyay S, Bhattacharya DK, Mandal C. Altered erythrocyte membrane characteristics during anemia in childhood acute lymphoblastic leukemia. Ann Hematol 2005; 84:76-84.

39. Niforou K, Cheimonidou C, Trougakos IP. Molecular chaperones and proteostasis regulation during redox imbalance. Redox Biol 2014;2:323-32.

40. Onat H, Inanc SE, Dalay N, Karaloglu D, Erturk N, Yasasever V. Effect of cisplatin on erythropoietin and iron changes. Eur J Cancer 1993;29:777-81.

41. Bosing B, Tunsmeyer J, Mischke R, Beyerbach M, Kastner SB. Clinical usability and practicability of Alfaxalone for short-term anesthesia in the cat after premedication with Buprenorphine. Tierarztl Prax Ausg K Kleintiere Heimtiere 2012;40:17-25.

42. Jenkins VK, Perry RR, Goodrich WE. Effects of cisdiamminedichloro platinum (II) on hematopoietic stem cells in mice. Exp Hematol 1981;9:281-7. 
43. Nowrousian MR, Schmidt CG. Effects of cisplatin on different haemopoietic progenitor cells in mice. Br J Cancer 1982; 46:397-402.

44. Wood PA, William JM. Cisplatin-associated anemia: an erythropoietin deficiency syndrome. Clin Invest 1995; 95: $1650-9$.

45. Abd El-Ghany MA, Ramadan AM, Ghozy SF. Nutraceutical effects of curcuma, ginger, celery, Yeast and honey on side effects of Gentamicin-induced nephrotoxicity in rats. World Appl Sci 2012;16:646-55.

46. Halliwell B, Cross CE. Oxygen-derived species: their relation to human disease and environmental stress. EHP 1994;102:5-12.

47. Cherubini A, Vigna GB, Zuliani G. Role of antioxidants atherosclerosis: an epidemiological and clinical update. Curr Pharm Des 2005;11:2017-32.

48. Robards K, Prenzler PD, Tucker G, Swatsitang P, Glover W. Phenolic compounds and their role in oxidative processes in fruits. Food Chem 1999;66:401-36.

49. Silici S, Ekmekcioglu O, Kanbur M, Deniz K. The protective effect of royal jelly against cisplatin-induced renal oxidative stress in rats. World J Urol 2010;29:127-32.

50. Nakajima Y, Tsuruma K, Shimazawa M, Mishima S, Hara H. Comparison of bee products based on assays of antioxidant capacities. BMC Complementary Altern Med 2009;8:4-9.
51. Vela L, De Lorenzo C, Perez RA. Antioxidant capacity of spanish honey and its correlation with some physicochemical parameters and polyphenolic content. J Sci Food Agric 2007;87:1069-75.

52. Bogdanov S, Jurendic T, Sieber R, Gallmann P. Honey for nutrition and health: $a$ review. J Am College Nutr 2008;27:677-89.

53. Krpan M, Markovic K, Saric G, Skoko B, Hruskar M, Vahcic N. Antioxidant activities and total Phenolics of acacia honey. Czech J Food Sci 2009;27:5245-7.

54. Mahaneem M, Sirajudeen KN, Swamy M, NikSoriani Y, Sulaiman SA. Studies on the antioxidant properties of tualang honey of Malaysia. Afr J Trad 2009;2:59-63.

55. Kassim M, Mansor M, Al-Abd N, Kamaruddin MY. Gelam honey has a protective effect against Lipopolysaccharide (LPS)induced organ failure. Int J Mol Sci 2012;13:6370-81.

56. Azab KS, Bashandy M, Salem M, Ahmed O, Tawfik Z, Helal H. Royal jelly modulates oxidative stress and tissue injury in gamma-irradiated male Wister albino rats. N Am J Med Sci 2011;3:268-76.

57. Achuba FI, Nwokogba CC. Effect of honey supplementation on heamatological parameters of Wistar albino rats fed hydrocarbon contaminated diets. Biochemistry 2015;27:44-9.

58. Tandon SK, Singh S. Protection of lead-induced toxicity by honey in rats. Indu Toxicol Res 1994;32:149-53. 